\title{
New Dynamic of China National Governance since the 18th National Congress-Based on the Inspecting Spots of the Politburo's Standing Committee
}

\author{
Muhesen Aleqing, Xudong Qi \\ School of Government, Beijing Normal University, Beijing, China \\ Email: alchen517@163.com
}

How to cite this paper: Aleqing, M., \& Qi, X. D. (2017). New Dynamic of China National Governance since the 18th National Congress-Based on the Inspecting Spots of the Politburo's Standing Committee. Open Journal of Political Science, 7, 229245.

https://doi.org/10.4236/ojps.2017.72018

Received: March 13, 2017

Accepted: April 11, 2017

Published: April 14, 2017

Copyright $\odot 2017$ by authors and Scientific Research Publishing Inc. This work is licensed under the Creative Commons Attribution International License (CC BY 4.0).

http://creativecommons.org/licenses/by/4.0/ (c) (i) Open Access

\begin{abstract}
Based on the Axial Coding from the inspecting spots and themes of the members of the Political Bureau in 2013-2016, this article is intended to explore the recent trends of national governance after 18th CPC National Congress. The Chinese politburo's standing committee members have been to all provinces in China, however, the visiting spots and themes are unbalanced. In order to achieve governance objectives, they have to think about the national policy and the particularity of each province. All the politburo's standing committee members have been paid more attention on decentralization and innovation. As we can see, the decentralization of authority between government and market has constituted strategic consensus. We found that the reform and innovation are the main policy and dynamic. The power of Chinese government and the activity of market have formed. They are willing to make a difference. Politburo's standing committee members are the third energy of Chinese reform or economy. Based on inspections of all the provinces of China, they can change any policy if they think it is not appropriate for the local development.
\end{abstract}

\section{Keywords}

The Latest Dynamic of Chinese Governance, Inspection Places and Themes, Inspection Density, Market-Augmenting Government, Axial Coding

\section{The Research Background}

General secretary Jinping Xi stated the two century strategic plan: the goal of a comprehensive well-off society in an all-round way will be achieved by the $100^{\text {th }}$ 
anniversary of founding of the communist party of China. Meanwhile, the goal of a democratic and civilized modern socialist country must be able to achieve by the 100th anniversary of the founding of new China (Xi, 2013). The realization of the strategic planning is based on national governance system and the modernization of national governance capacity. Since the 18th CPC National Congress, Chinese governance structure presents a series of new features and dynamic. This paper explores new dynamic governance system in contemporary China from two aspects of practice and theory based on the politburo's standing committee members' inspecting spots and themes in 2013-2016. Since the 18th CPC National Congress, national leaders make contingent decisions for inspections to solve the problems and promote the implementation of strategic planning, by flexibly adjusting the power of property and authority. The whole process just likes the guidance and the satellite orbit. The satellite should run along the orbit, but orbit will change according to the task, in order to achieve the mission.

\section{Research Methods}

"Grounded theory" is one of the famous methods of Qualitative research put forward by the Glaser and Strauss, using a systematic procedure for a particular phenomenon to induce a theory. Based on the grounded theory, this study adopts the method of axial coding. Axial coding method is using so-called "reason condition - phenomenon - situation - intermediate conditions - action/interaction strategy - results" coding mode, and it is a process of the various linked concepts of organization in open coding.

The process of this study is: collection of full sample cases - secondary theme excavation and coding - first level theme induction - theory evolution extraction. 1) Full sample case collection. This article comprehensively and accurately collected all 31 provinces' cases ${ }^{1}$ inspected by Politburo's standing committee from January 2013 to June 2013 in China. All the inspection cases gathered from authoritative news broadcasts and inspection tracks of politburo's standing committee. "We should continue to adopt the way of traditional methods of collecting data for specific needs and we also must be good at using the modern network information technology and various data sources to collect all relevant data (Li, 2014).” This database is not a sample case, but a full sample case structure, so the reliability and validity of the empirical facts are high. 2) Secondary themes are extracted from inspection content. Based on the inspection theme of the Politburo's standing committee members, using encoding method of grounded theory, this article extracts and encodes each inspection theme to form a series of secondary themes, in order to find the key changes of state leader's inspection. 3) Grounded theory emphasizes the promotion of the theory from information; it's the process of information induction from the lower layer to the upper layer of

${ }^{1}$ The 31 provinces includes: Beijing, Shanghai, Chongqing, Tianjin, Zhejiang, Jiangsu, Fujian, Shandong, Guangdong, Guangxi, Yunnan, Guizhou, Sichuan, Hunan, Hubei, Jiangxi, Anhui, Henan, Hebei, Shanxi, Shaanxi, Inner Mongolia, Liaoning, Jilin, Heilongjiang, Xinjiang, Gansu, Ningxia, Qinghai, Tibet, Hainan. 
data. Based on the summarizing of secondary themes, the one-level theme is formed by the axial coding. 4) Theory evolution extraction. This research analyzes new dynamic of national governance system since 18th CPC National Congress, based on quantitative and distribution analysis of the one-level themes and secondary themes. "Unlike the general theory, the grounded theory does not carry on the logical deduction to the hypothesis that the researcher set up in advance, Starts with the data inductive analysis (Chen, 2000)".

\section{Allocation of National Leader's Inspection Resources: Unbalanced Distribution}

"Experimentation precedes popularization" is the distinctive characteristic and successful experience of the institutional change during the period of China's reform and opening up. The institutional innovation follows the process of system design-experimentation-improvements-popularization. The state generally choose specific experiment places to carry out system test and implement preferential policies and special system before promoting nationwide institutional change. They modify and optimize the design of the original system, and then gradually promote the new system nationwide, through the process of trial and error of institution experimental places. Pilot policy is a kind of test under the hierarchy that brings valuable grassroots advice and local experience into the national level of policy-making (Heilmann, 2008). State leaders inspect a variety of local institutional innovation models based on the top-level design, and according to the summary of pilot area performance, proceed system improvement and promotion system, in order to promote the modernization of governance. $\mathrm{Xi}$ general secretary always emphasizes: "we persist in and improve the system of investigation before decision-making" (Xi, 2011). From January 2013 to June 2016, Politburo's standing committee seven members fully inspected the 31 provinces for a total of 149 times, the average of each member's inspection is 21.2 times, each province inspected an average of 4.81 times.

From the analysis of inspection density, 31 provinces can be divided into three levels. High density (more than 7 times), including Henan (9 times), Beijing (8 times), Shandong (8 times), Fujian (7 times), Tianjin (7 times), Inner Mongolia (7 time). All the seven members of the Politburo's standing committee inspected Henan province. The general secretary inspected Henan Province for twice: first, the general secretary inspected Lankao County in Henan province (March 17, 2014) for the party's mass line educational practice. Second, the inspection line of general secretary (May 10, 2014) is Zhengzhou Lankao County-Weishi County - Zhengzhou City, cross-border trade e-commerce services pilot, international land port, China Railway Engineering Group Co. ltd. The themes of the inspection are the party's mass line of educational practice, the three rural issues, trade and logistics industry and enterprise technology innovation.

Medium density (4 to 6 times) including Sichuan province (6 times), Hubei (6 times), Shanghai (5 times), Chongqing (5 times), Jiangsu (5 times), Zhejiang (5 times), Guangdong (5 times), Guizhou (5 times), Hunan (5 times), Hebei (5 
times), Jilin (5 times), Xinjiang (5 times), Gansu (5 times), Guangxi (4 times), Yunnan (4 times), Liaoning (4 times), Hainan (4 times). Take Hainan Province as an example, in order to implement the spirit of the 18th CPC National Congress and inspect the construction of Hainan international tourism island, General Secretary Xi (April 8, 2013) visited Haikou and Sanya. Prime minister Keqiang Li (April 10, 2014) paid a visit to Sanya to inspect the city's reform of administrative examination and approval, construction of the people's livelihood, and a large innovation entrepreneurship. Prime minister Keqiang Li (March 26, 2016) also inspected international tourism island construction and "multiple-plan integration" in Hainan. Two months later, Vice Premier Gaoli Zhang inspected the Hainan province with the same theme. Low density ( 1 - 3 times) includes Anhui (3 times), Shanxi (3 times), Shanxi (3 times), Heilongjiang (3 times), Tibet (3 times), Jiangxi (2 times), Ningxia (2 times), Qinghai (1 times).

Is there a correlation between the frequency of national leader's inspection and the economic growth of provinces? To solve this problem, an exploratory scatter diagram analysis (see Figure 1) and a correlation test by SPSS 16.0 software are carried out. The analysis result of two sets of data correlation coefficient is 0.045 , significant index is 0.811 , which shows that there is no significant correlation between the level of GDP growth and the inspection frequency. To further investigate the correlation between the leader's inspection frequency and the economic growth of provinces from the East-Midland-West regions, the

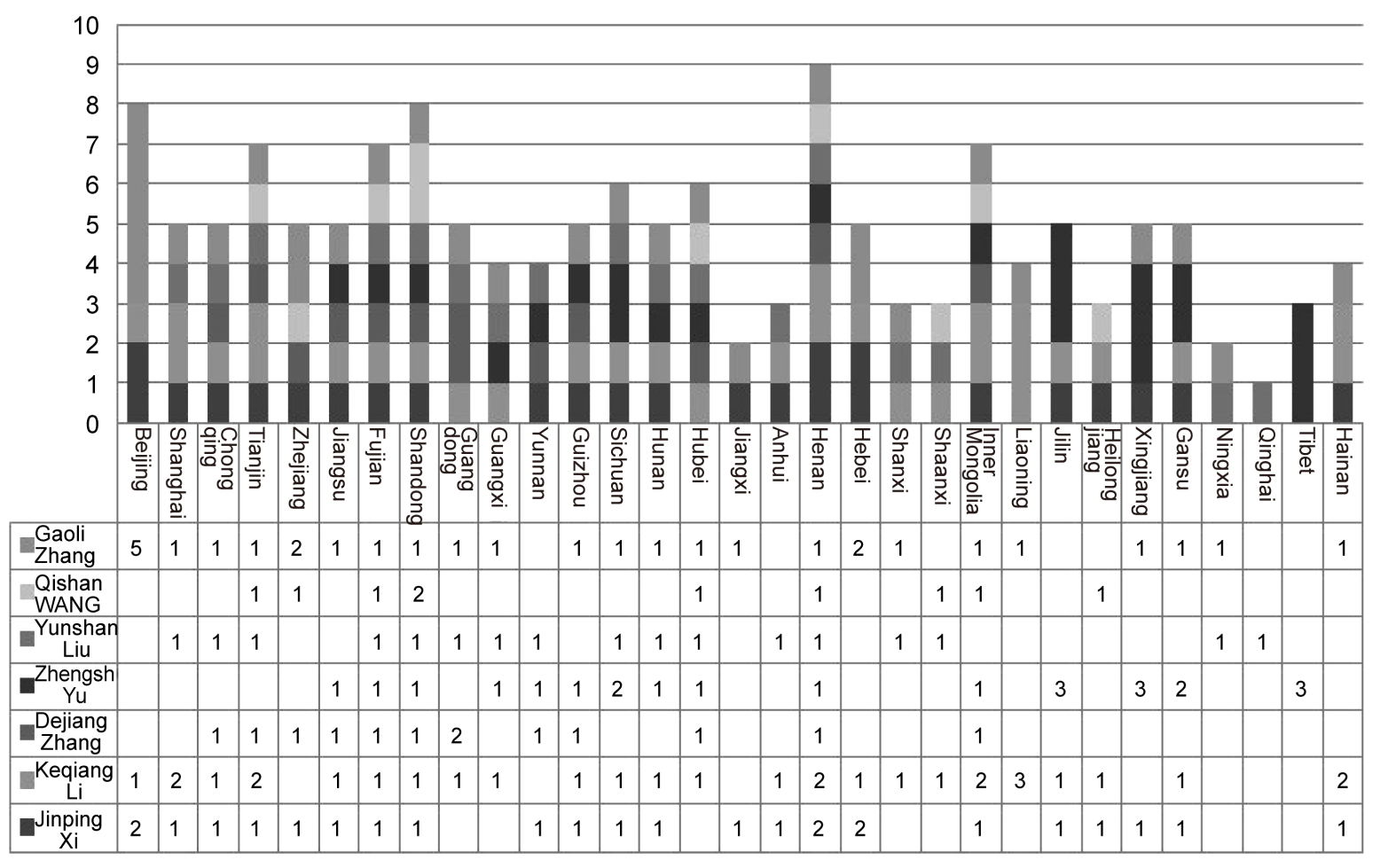

Figure 1. The frequency distribution of Central Politburo's standing committee of the CPC inspection 31 provinces (2013.12016.6). 
analysis result of correlation coefficients are $0.32,0.349,0.142$, significant indexes are $0.311,0.357,0.695$, this shows that there is no significant correlation between the inspection frequency and GDP growth rate.

Some provinces with high GDP growth rate rarely inspected by the Politburo's standing committee, while some provinces with low GDP growth rate more inspected by the Politburo's standing committee. Provinces with nearly $12 \%$ GDP growth rate, got 3 inspections, provinces with 4\% GDP growth rate got 4 inspections so on (see Figure 2). This also shows that there is no further significant correlation between the inspection frequency and GDP growth rate.

The national leaders' inspection is not simply based on the economic development performance, but also based on the comprehensive consideration of revolutionary tradition, red culture, economic performance and many historical factors. To grasp core spirit of the leaders, we need to analyze the themes of inspections not the inspection frequency distribution, and then explore the new features, new dynamic of governance structure since the 18th CPC National Congress.

\section{Changes of Inspection Themes and New Dynamic of Governance}

Relative to the inspection frequency and inspection area, the national top policymakers' inspection themes reflect more about the new features, new dynamic of Chinese governance structure since the 18th CPC National Congress. This research forms 22 inspection themes (Figure 3) from the Politburo's standing committee inspection tracks and the themes of coding the whole samples. All seven members of Politburo Standing Committee have different division of duties, so they each focus on different inspection theme, but there is in common.

Since 2013, general secretary Jinping Xi inspected 25 times out of Beijing, covering 19 topics, he is one of the Politburo Standing Committee with the

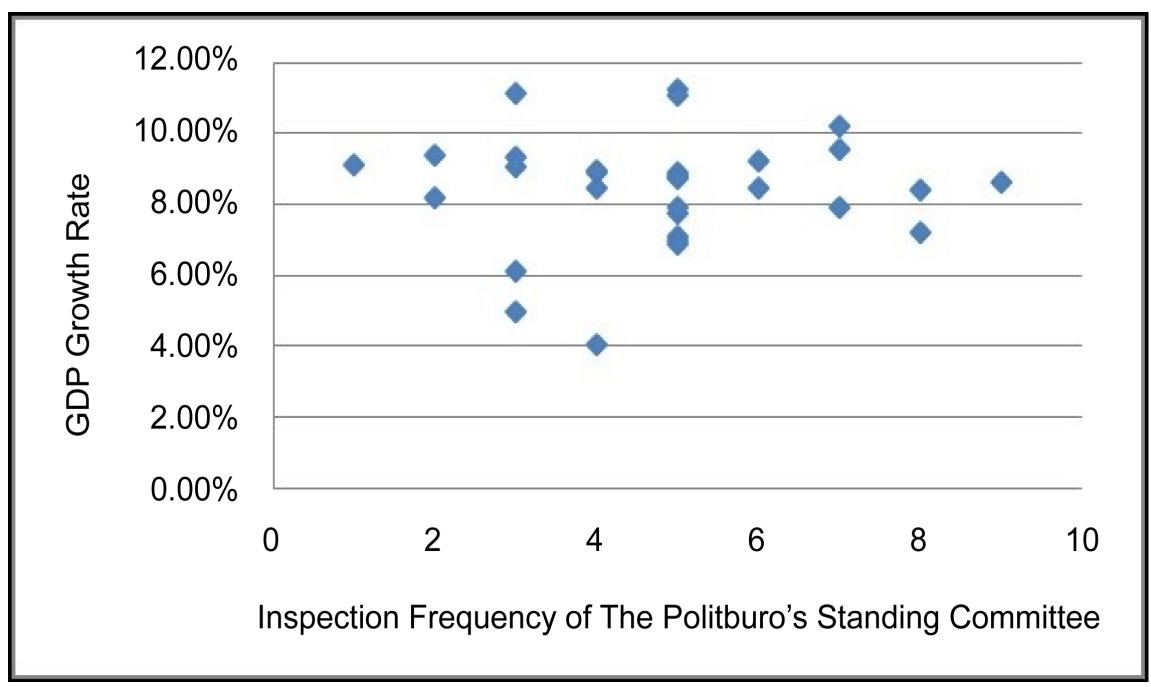

Figure 2. 31 provinces inspected frequency and GDP growth rate (2013.1-2016.6). (GDP data are from the National Bureau of Statistics). 


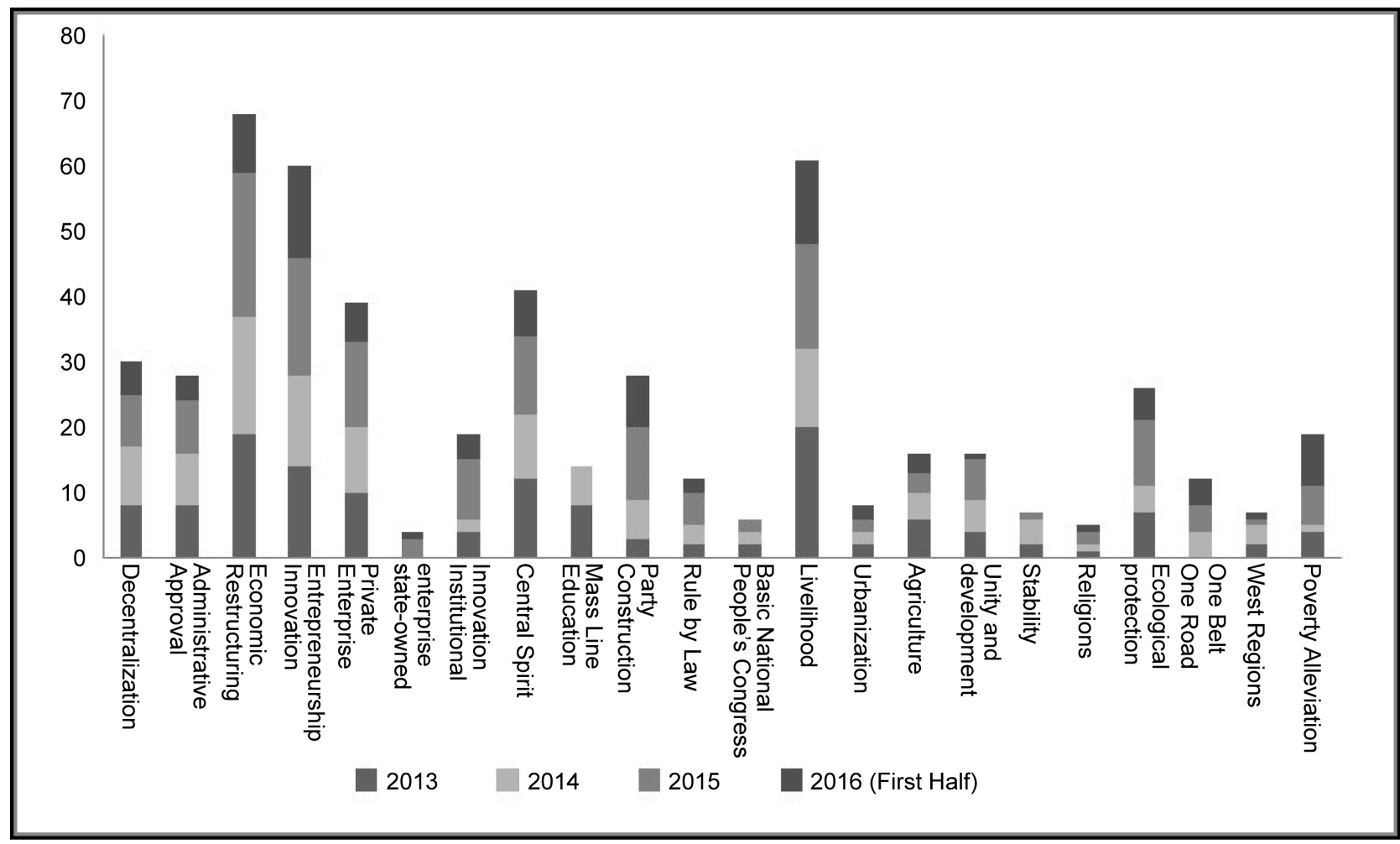

Figure 3. Distribution of inspection themes of the Politburo's standing committee (2013.1-2016.6).

maximum frequency of inspection and the most diverse themes. The first four inspection themes are: the adjustment of economic structure (18 times), innovation and entrepreneurship (18 times), People's livelihood project (16 times), the development of private enterprises (10 times). Premier Keqiang Li inspected 31 times, including 14 themes, the prime minister's inspection themes are mainly focused on the economy, people's livelihood and national strategy. The first five inspection themes are: innovation and entrepreneurship (24 times), the adjustment of economic structure (18 times), decentralization (12 times), reform of the administrative examination and approval (12 times), the people's livelihood project (12 times). Dejiang Zhang, chairman of Politburo's standing committee, inspected a total of 13 times, including 13 key themes. The key themes are: the construction of grass-roots People's Congress system (6 times), the strategy of governing the country according to law (4 times), implementation the central spirit (3 times), the adjustment of economic structure (3 times). Zhengsheng $\mathrm{Yu}$, chairman of the Chinese People's Political Consultative Conference (CPPCC), inspected 21 local places, with 17 inspection themes. He mostly focused on the development and stability of ethnic minority areas. The first four themes of the inspection are: national unity and development (14 times), people's livelihood project (14 times), the implementation of the central spirit (8 times), the adjustment of economic structure (8 times). Yunshan Liu, Secretary of the Central Committee, inspected 17 times out of Beijing, covering the 17 inspection themes. The first three themes of the inspection frequency are the work of Party building at the basic level (12 times), the implementation of the central spirit (10 times) 
and the poverty alleviation work (8 times). Qishan Wang, Secretary of the CPC, inspected 10 times, including 5 themes, mainly focused on the work of Party building at the basic level ( 7 times), implementation of the central spirit (3 times), the party's mass line education practice (2 times), and less involved in economy and people's livelihood themes. Vice Premier Gaoli Zhang inspected a total of 30 times, including 15 themes. The first three theme are the adjustment of economic structure (20 times), the ecological and environmental protection work (16 times), innovation and entrepreneurship (15 times), Gaoli Zhangmostly focused on ecological and environmental protection in Politburo's standing committee than other members do. His inspection theme distribution and inspection frequency is similar with Prime Minister Keqiang Li.

In summary, the inspection themes of Politburo's standing committee are based on the different division of functions. The general secretary inspects the overall situation (see Figure 4) and mostly focused on economic growth, innovation and entrepreneurship, people's livelihood. The prime minister focused on the economy and people's livelihood, Secretary Qishan Wang focused on Party discipline and Party construction, Zhengsheng Yu focused on the unity and stability of minority areas. Although the inspection themes are different, but all the seven Politburo's standing committee members are highly emphasized the importance of decentralization, innovation and entrepreneurship and livelihood projects. With the Chinese economy entered the new normal state, the reform got into the deep water and crucial areas. National leader's inspections can reflect the new dynamic and trend of national governance. If we want to extract

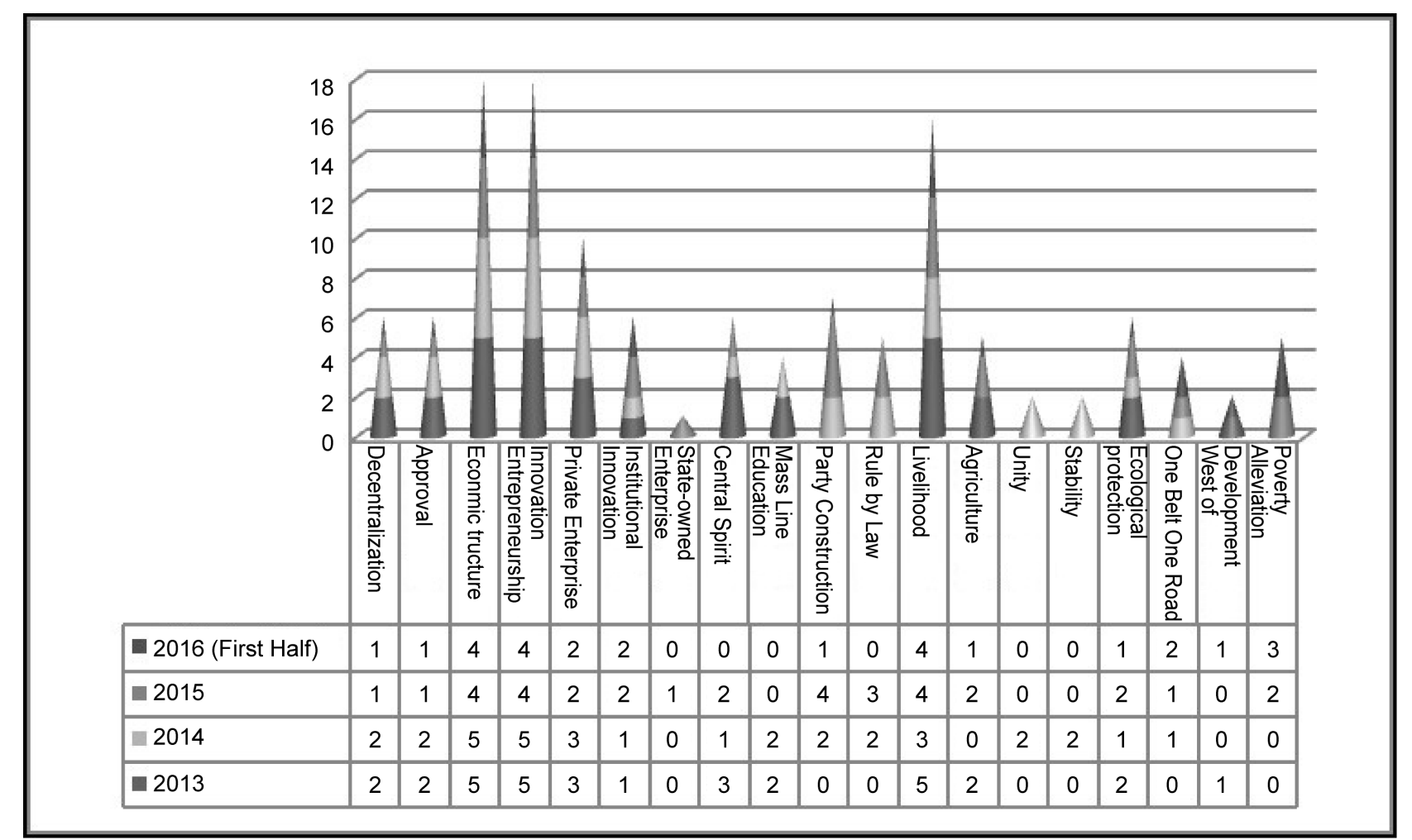

Figure 4. General Secretary's inspection themes (2013.1-2016.6). 
the core ideas and theoretical main line of the central government from the 22 national leader's inspection themes, we need to use the axial coding of grounded theory. Based on the secondary theme of the inspection, the first level theme is formed by the method of axial coding. This coding work of this stage clearly points to the theoretical dimension to form the analytical and interpretive theory.

\section{Dynamic Change of Governance: Axial Coding and Theory Construction}

The main line of the theory is the reasonable connection between the concept of various themes, which is closely linked to form an integral whole. Axial coding more clearly show a new dynamic of national governance since the 18th CPC National Congress through building the first level themes. Based on the hot inspections of national leaders, the national governance formed a triple organic linkage development power: market power, government power, inspection power. 1) From the perspective of market power, the state plays the role of "strengthening the market-oriented government". The government let the market play a decisive role in allocation of resources, and stimulate the mass innovation and entrepreneurship through decentralization. 2) From the point of view of government power, on the one hand, the central government promotes the standardization of power through efficient centralization and anti-corruption in order to place the power of government on the right law track. On the other hand, the central government brings various governance forces into strategic planning through a series of top-level design. 3) From the point of inspection power, the inspection of national leaders is a valuable political resource under China's national conditions. On the one hand, in view of the key issues, the national leaders selectively carry out high density provincial inspection based on the top-level design and actual situation of each province. National leaders, on the other hand, change the strategic plan for dynamic adjustment and make camera decisions through process of "trial and error" exploration inspections, in order to promote major policy implementation.

The first-level theme includes Decentralization of state power and market (47.16\%), Standardization of the operation of government power (19.20\%), collaborative governance between central and local governments under the unified strategic planning (33.64\%). Decentralization of state power and market divided into 7 secondary themes, standardization of the operation of government power divided into 5 secondary themes, collaborative governance between central and local governments under the unified strategic planning concluded 10 secondary themes (see Table 1).

\subsection{Development Power: Strengthening Market Oriented Government and Market-Driven}

Since the 18th CPC National Congress, national governance power has shifted to two wheel drive, that is, the cooperation of country and the market. On the one 
Table 1. Axial coding and theoretical framework.

\begin{tabular}{|c|c|c|c|}
\hline First-level theme & Proportion & Secondary theme & Proportion \\
\hline \multirow{7}{*}{ Decentralization of state power and market } & \multirow{7}{*}{$47.16 \%$} & Streamlining government and delegating authorities & $5.70 \%$ \\
\hline & & Reform of administrative examination and approval & $5.31 \%$ \\
\hline & & Innovation and Entrepreneurship & $11.42 \%$ \\
\hline & & Reform of state-owned enterprises & $0.76 \%$ \\
\hline & & Private enterprise development & $7.41 \%$ \\
\hline & & Economic restructuring & $12.94 \%$ \\
\hline & & institutional innovation & $3.61 \%$ \\
\hline \multirow{5}{*}{ Standardization of the operation of government power } & \multirow{5}{*}{$19.20 \%$} & Implementation the central spirit & $7.80 \%$ \\
\hline & & Practice of Mass line education & $2.66 \%$ \\
\hline & & Grass-roots party construction & $5.32 \%$ \\
\hline & & The rule of law strategy & $2.28 \%$ \\
\hline & & Basic National people's Congress System & $1.14 \%$ \\
\hline \multirow{10}{*}{$\begin{array}{l}\text { Collaborative governance between central and local } \\
\text { governments under the unified strategic planning }\end{array}$} & \multirow{10}{*}{$33.64 \%$} & One Belt, One Road strategy & $2.28 \%$ \\
\hline & & Development of the West Regions & $1.33 \%$ \\
\hline & & Modern agriculture & $3.04 \%$ \\
\hline & & New-type urbanization & $1.52 \%$ \\
\hline & & Livelihood project & $11.60 \%$ \\
\hline & & Poverty alleviation & $3.61 \%$ \\
\hline & & Ecological protection & $4.94 \%$ \\
\hline & & Unity and development in Ethnic Areas & $3.04 \%$ \\
\hline & & Stability work & $1.33 \%$ \\
\hline & & Religious affairs & $0.95 \%$ \\
\hline
\end{tabular}

hand, let the market play a decisive role in the allocation of resources, stimulate the public innovation and entrepreneurship through decentralization. As an escort of market, On the other hand, the government brings various forces into strategic plan through a series of top-level design. The American political scientist Mancur Olson proposed "Market-augmenting Government" concept in the book named "Power and Prosperity", "if a government has enough power to create and protect individual property rights and able to enforce all kinds of contracts, we can regard it as market-intensified government (Mancur, 2005)." The third Plenary Session of the 18th CPC Central Committee proposed that economic system reform is the main points of comprehensive deepening reform, and the core issue is to deal with the relationship between the government and market. "The third Plenary Session of the 18th CPC Central Committee emphasized that the market plays a decisive role in the allocation of resources, which means that the we need to eliminate some intervention, distortion of the market, so that resources are allocated by the market. For one thing, government can 
make the economy get better according to the development of comparative advantage. For another, we can solve social and economic problems left since the reform and opening-up (Lin, 2014)". Judging from the inspection themes distribution of the Politburo's standing committee, the decentralization between the government and market has become the primary focus of the Politburo Standing Committee. The separation between state power and market is the highest proportion of $47 \%$. "Decentralization of state power and market" can be further divided into a series of secondary themes, according to the concerns of Politburo's standing committee: the adjustment of industrial structure (68), entrepreneurship and innovation (60), the development of private enterprises (39), Streamlining government and delegating authorities (30), Reform of administrative examination and approval (28), institutional innovation (19) (see Figure 5).

Thus, decentralization of state power and market has constituted the strategic consensus: the state eliminate the market interference of local power by using power centralization tool, and fully unleash innovation and vitality of the market through streamlining government and delegating authorities. Since the 18th CPC National Congress, the central government plays the part of "the first action group" of institutional innovation in China, by breaking the small pattern of regional power-interests, in order to escort the market to stimulate the vitality of innovation. The government functions of the release can be returned, the regulation is regulated. The state advocates of limited government functions in the field of market leading. The market mechanism transferred from the "basic function" to "decisive function". "On the microeconomic level, the government should adopt the negative way of management, namely, the government should

\begin{tabular}{|c|c|c|c|c|c|c|c|}
\hline \\
\hline \\
\hline \multicolumn{8}{|c|}{ Private Enterprise } \\
\hline \multicolumn{8}{|c|}{$\begin{array}{l}\text { Innovation } \\
\text { Entrepreneurship }\end{array}$} \\
\hline \multicolumn{8}{|l|}{ Economic Restructuring } \\
\hline \multicolumn{8}{|l|}{ Administrative Approval } \\
\hline \multicolumn{8}{|c|}{ Decentralization } \\
\hline & \multicolumn{2}{|l|}{10} & 30 & 40 & 50 & 60 & 80 \\
\hline & Decentralization & $\begin{array}{l}\text { Administrative } \\
\text { Approval }\end{array}$ & $\begin{array}{l}\text { Economic } \\
\text { Restructuring }\end{array}$ & $\begin{array}{l}\text { Institutional } \\
\text { Innovation }\end{array}$ & $\begin{array}{l}\text { Private } \\
\text { Enterprise }\end{array}$ & $\begin{array}{l}\text { State-owned } \\
\text { Enterprise }\end{array}$ & $\begin{array}{l}\text { Institutional } \\
\text { Innovation }\end{array}$ \\
\hline 2013 & 8 & 8 & 19 & 14 & 10 & 0 & 4 \\
\hline 2014 & 9 & 8 & 18 & 14 & 10 & 0 & 2 \\
\hline 2015 & 8 & 8 & 22 & 18 & 13 & 3 & 9 \\
\hline 2016 (First Half) & 5 & 4 & 9 & 14 & 6 & 1 & 4 \\
\hline
\end{tabular}

Figure 5. Distribution of inspection themes of "decentralization of state power and market". 
formulate a set of strict laws and strict enforcement of the law. On the macroeconomic level, the government should adopt a positive approach to management, namely, the government guide and regulate the market economy as a whole by adopting the formulation and implementation of public policy, so as to make the development of the market economy is conducive to social fairness benefit all members of society (Zhang, 2014)".

\subsection{Government Power: Power Standardization and Cooperative Governance}

Market economy is a contract economy. With the continuous improvement of the free order derived from the market economy, the government power should be restrained by the "spontaneous order" and the economic law. From the point of the power operation mode, the central government promotes the standardization of power to bring government power into the rule of law through efficient centralization and anti-corruption. The Politburo's standing committee highly stressed the standardization of relations between central power and local power in the inspections. The inspection theme proportions are as follows, the grassroots party construction accounted for $28 \%$, implementing spirit of 18 th CPC National Congress, NPC and CPPCC accounted for $38 \%$, the strategy of governing the country by law accounted for $13 \%$, the practice of Mass line education accounted for 15\%, the basic National people's Congress System accounted for $6 \%$ (see Figure 6).

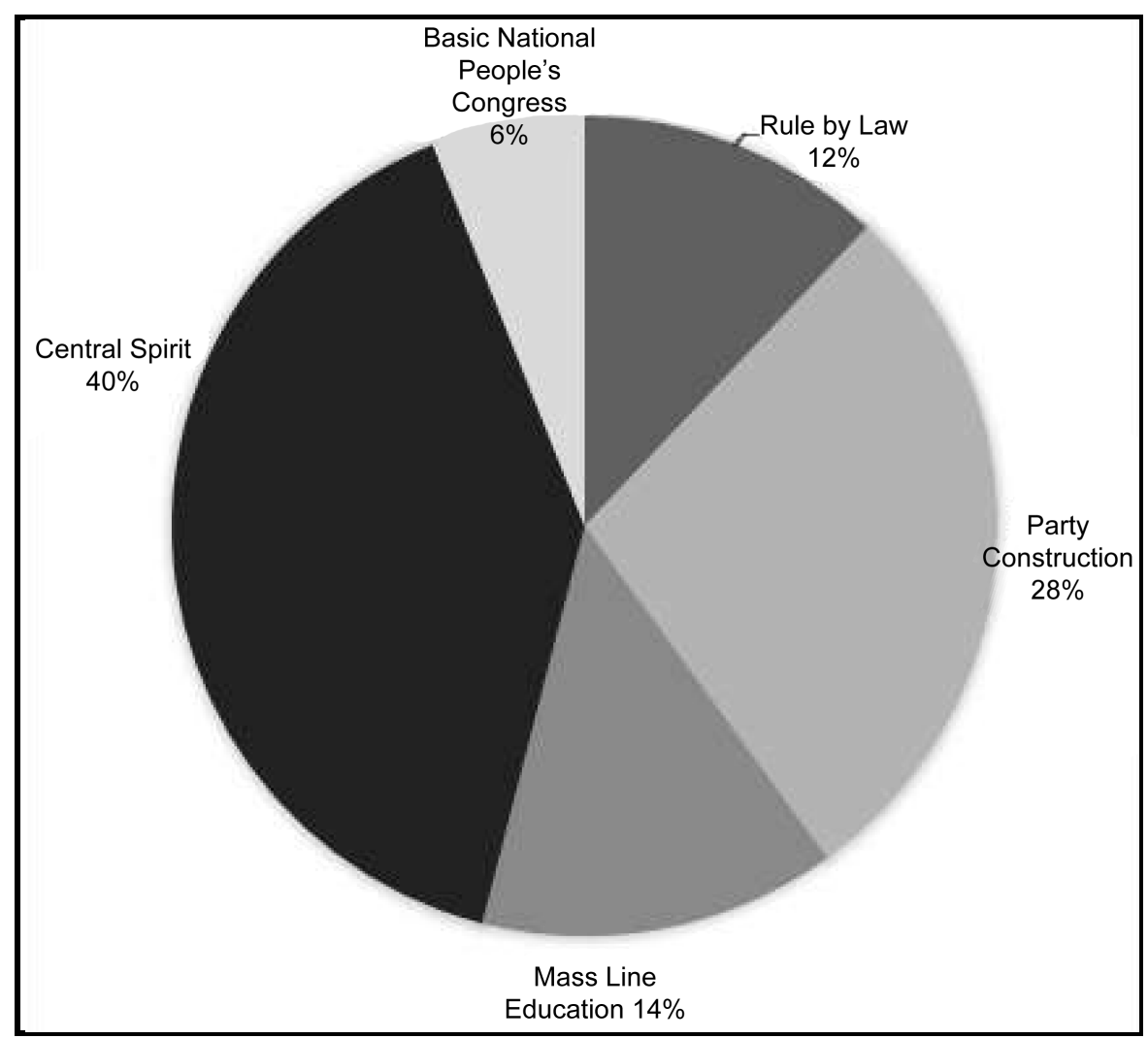

Figure 6. Distribution of the "power standardization" inspection themes. 
In the form of the unitary state structure, the local government is entrusted by the central government, so it is necessary to implement the central government policy and transfer information. However, in addition to implementation of the central government's fundamental policy, the provincial government shows relatively independent power preference. The higher authorities have policies, the localities have their counter-measures. The local government regard central government policy implementation as game strategies by "playing edge ball" to get investment and construction projects. This not only damages the interests of the country as a whole, but will eventually damage local interests. "Over the years, both the central and local government are engaged in a lot of institutional norms, but some of them are too principle and lack of specific quantitative standard; Some of them can't form systematic systems and can't produce a comprehensive effect, because of the lack of mutual cohesion and coordination; Some of them are too general and flexible, so the problems are that corruption is intensified instead of curbing it (Xi, 2016)."

With the reform and opening-up going into the deep water and crucial areas, there is need for a strong central government making unified strategic plans through top-level design. The standardization of the relationship between the central and local powers has become the basic trend of development since the 18th CPC National Congress, which is the strategic basis of the relationship between the central authority and local authority." The proposal focused on cleaning up, canceling, integrating the central government and local government regulations that scattered in the constitution, laws, and put them into a unified legal texts, eventually, lay down a "Central government and local government relationship law" (Zhang, 2016). In constitutional structure, we should determine the central government and local government powers clearly, and establish property rights system of interdependence on this basis through a series of laws and regulations.

"Top-level design" means that the central government should be the "helmsman", carry out the general design of reform and system planning. This article analyze central strategic planning and design ideas from the point of the inspection themes, the Politburo's standing committee inspection focused on livelihood projects (61 times), modern agriculture (16 times), poverty alleviation (19 times), New-type urbanization (8 times), One Belt, One Road strategy (12 times), ecological protection (26 times) since the 18th CPC National Congress (see Figure 7).

State leaders integrate the central authority and local authority into the overall authority through negotiations. Meanwhile State leaders implement the strategic planning by breaking the obstruction of local interests and arousing the enthusiasm of the central, provincial and municipal parties during in inspections. Gerard Roland believes: "China's relationships between central and local provides incentives and flexibility in policy making for local government, and facilitate the pilot policy implemented better in local places (Roland, 2000)". 


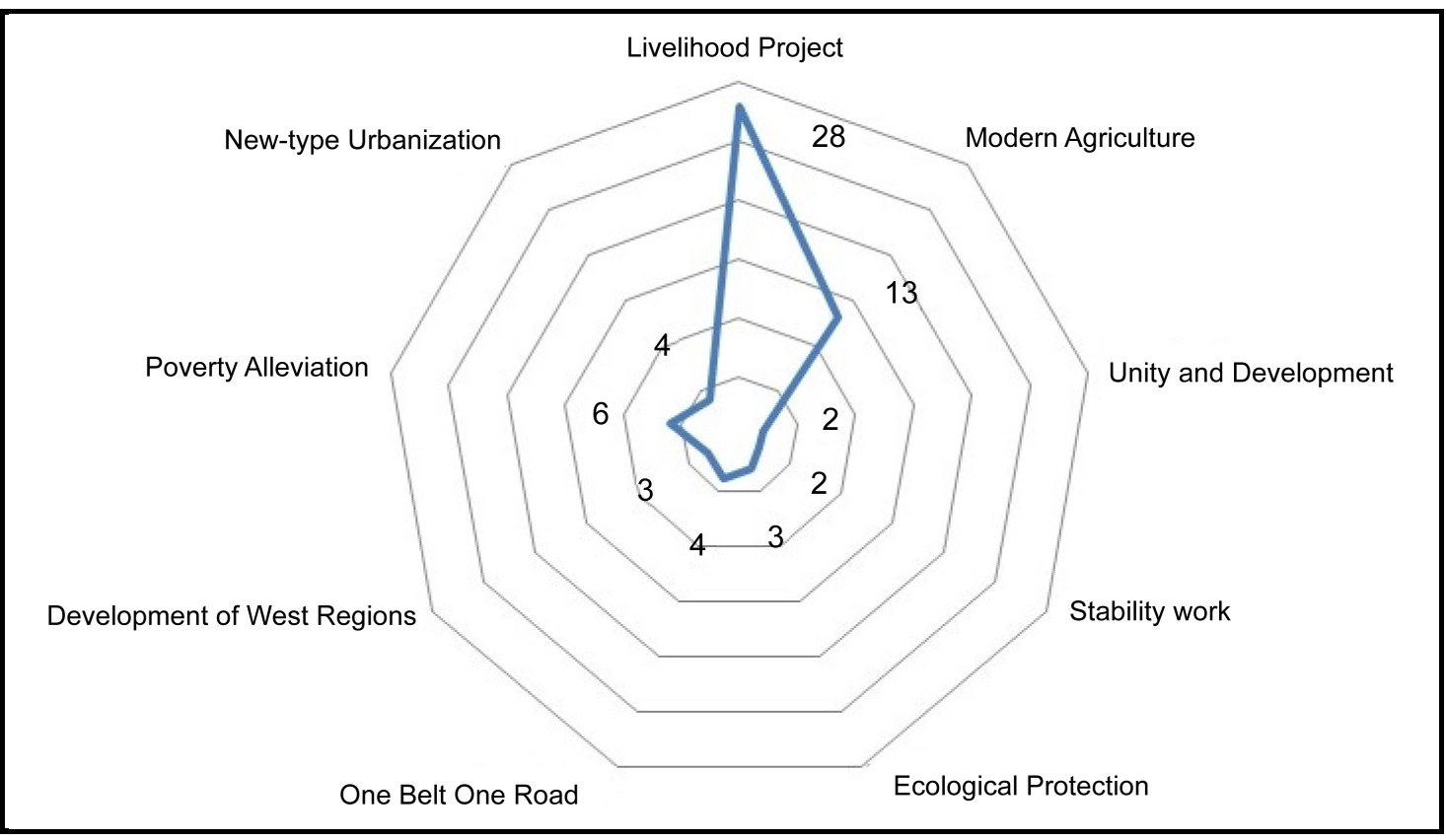

Figure 7. Distribution of "collaborative governance" inspection themes.

\subsection{Inspection Power and Dual Function}

The first function is that allocation of inspection resources fits with regional development center. The state leaders' inspection focus on important political resources which allocated unevenly, but based on the implementation of strategic planning. According to the development center of each provinces, the leaders implement the national strategic goals in a most effective way. China shows unbalanced pattern of development, the situation in East-Midland-West area is different, so the each part has different mission and development tasks. We can find out from the data distribution, allocation of inspection resources fits with the regional development center.

The 12 provinces in the eastern part of the China considered as economic lifeline, the general secretary and Politburo's standing committee members inspected the eastern part with highest frequency, respectively reached the 11 times and 67 times (see Table 2). More than $70 \%$ of large and medium-sized cities located in $18000 \mathrm{~km}$ coastal economic belt of China. "Pearl River Delta Urban Agglomeration" has become the "first development pole" after more than 30 years of development. "Yangtze River Delta Urban Agglomeration" has become the "second development pole" with Shanghai, Zhejiang and Jiangsu working in coordination. Beijing, Tianjin, Hebei region has become "third development pole". The eastern coastal region is not only the national economic lifeline, but also the innovation driven development strategy engine. Therefore, the state leaders inspect the pros and cons of policy experiment with high density. All the top three inspection themes of General Secretary and the Politburo's standing committee are the economic restructuring, innovation and entrepreneurship, private enterprise development. The general secretary mostly stressed the economic restructuring. 
Table 2. Regional allocation of inspection resources (2013).

\begin{tabular}{|c|c|c|c|}
\hline & East & Midland & West \\
\hline $\begin{array}{l}\text { Frequency of inspection of } \\
\text { General secretary }\end{array}$ & 11 & 8 & 6 \\
\hline $\begin{array}{l}\text { Frequency of inspection of the } \\
\text { Politburo's standing committee }\end{array}$ & 67 & 43 & 39 \\
\hline \multirow{3}{*}{$\begin{array}{l}\text { The first three inspection } \\
\text { themes of General secretary }\end{array}$} & Economic restructuring & Economic restructuring & Livelihood project \\
\hline & Innovation and Entrepreneurship & Livelihood project & Economic restructuring \\
\hline & Private enterprise development & Innovation and Entrepreneurship & $\begin{array}{l}\text { Poverty alleviation, } \\
\text { Modern agriculture }\end{array}$ \\
\hline \multirow{3}{*}{$\begin{array}{l}\text { The first three inspection } \\
\text { themes of the Politburo's } \\
\text { standing committee }\end{array}$} & Innovation and Entrepreneurship & Economic restructuring & Livelihood project \\
\hline & Economic restructuring & Innovation and Entrepreneurship & Economic restructuring \\
\hline & Private enterprise development & Livelihood project & $\begin{array}{l}\text { Poverty alleviation, Innovation } \\
\text { and Entrepreneurship }\end{array}$ \\
\hline Focus of inspections & economic development & $\begin{array}{l}\text { economic development } \\
\text { and social development }\end{array}$ & social development \\
\hline
\end{tabular}

The midland 9 provinces is the strategic hinterland of national development. The general secretary and Politburo's standing committee members inspected the midland for 8 times and 43 times (see Table 2). Inspections frequency of midland was significantly lower than that of the eastern region and slightly higher than that of the western region. The first three inspection themes are economic restructuring, people's livelihood projects, innovation and entrepreneurship. Compared with the eastern area, the state leaders emphasize not only the economic development and entrepreneurship, but also the people's livelihood project in midland inspections, which reflects the inequality in China regional economic development and different national governance strategy deployment.

The 10 provinces in the western area are the strategic rear of the national development. The general secretary and the Politburo's standing committee members inspected the western area for 6 times and 39 times (see Table 2), slightly lower than the frequency of central regions. The themes of the inspection showed a significant difference, compared with the economic theme of the East, the top three inspection themes in the western area are people's livelihood projects, economic restructuring, poverty alleviation and modern agriculture. Social development and national unity has become a focus of concern for the Politburo's standing committee.

Thus, each region takes different missions in the national development strategy. The allocation of national inspection resource fits with the regional development center. The eastern regions focus on economic development, the central regions focus on both economic development and social development, the western regions focus on social development. According to the focus of regional development center, national leaders selectively and effectively inspect regions to 
achieve national strategic goals.

The second function is dynamic change of track. The reform and innovation of government behavior is largely a process of "trial and error" exploration. "Governments at all levels need to acquire practical knowledge about the market economy theory and market operation through the exploration of "trial and error". According to the objective requirements and the process of the market system development, governments constantly adjust their own mode of function orientation and behavior patterns ( $\mathrm{He}, 2008)$ ". In national condition of China, the central government formed the strategic track of national development through the top-level design, but in the implementation of the national strategic planning, there are all sorts of problems, obstruction, and unexpected dynamic factors. Therefore, the inspection of national top leaders has become the power of strategic contingency readjustment.

National leaders carry out inspection survey with the realistic and rigorous scientific attitude to analyze the advantageous and disadvantageous of policy practice comprehensively. "When the state leading organs set policies, more than ninety percent of the time spent for the investigation and research, less than ten percent of the time spent for making decisions (Chen, 1986)." This process is widely absorbs the local government and the public opinion, a variety of information and interest demands form vertical structure through from top to bottom and from bottom to top flow mode. "Chinese today give full consideration, before making any actions and developed called "new democratic centralism" decision-making system, including "Coming from mass and going to mass" and a series of specific procedures and methods (Zhang, 2014).” Secretary Jinping Xi carried out investigations in Chongqing, Anhui, Heilongjiang provinces in the first half of 2016, and underlined the implementation of the reform tasks. In the good economic development area, Jinping Xi stressed the supply-side structural reform, effective resolution of overcapacity, industrial restructuring, development of strategic emerging industries and modern service industry, to enhance the power of sustained economic growth in the end. During inspection in the birthplace of rural reform in Anhui Xiaogang village, Jinping Xi underlined the importance of improving the basic rural operation system and adherence to the collective ownership of rural land, the basic household operations and stable land contract relationship. Heilongjiang is one of the provinces under greater pressure of economic restructuring. Jinping Xi emphasized that Heilongjiang is facing difficulties in economic restructuring, we should focus on optimizing the industrial structure. Thus, the reform and innovation form the main line of development, market power and government power combined as two-wheel driven of reform and innovation, the national leaders inspection become a power for policy implementation and adjustment, so as to form an organic governance of power system.

\section{Conclusion}

We can get three conclusions by axial coding based on national leader's inspec- 
tion track analysis, since the 18th CPC National Congress.

The first conclusion. The Politburo's standing committee seven members inspected the 31 provinces of full-coverage, but the allocation of inspection resources showed uneven distribution. Each province takes different missions in the national development strategy, and the allocation of inspections resource fits with the regional development center: the eastern regions focus on economic development; the central regions focus on both economic development and social development; the western regions focus on social development. National leaders selectively and effectively inspect regions to achieve national strategic goals.

The second conclusion. The inspection themes of Politburo's standing committee members are based on the different division of functions, but all the seven members are highly emphasized decentralization, livelihood projects, innovation and entrepreneurship. Thus, decentralization of state power and market has constituted the strategic consensus: the state eliminates the market interference of local power by using power centralization tool, and fully unleashes innovation and vitality of the market.

The third conclusion. Through axial coding based on the Politburo's standing committee inspection track analysis, we can find out that the reform and innovation form the main line of development. Market and government are the major power of reform and innovation. The national leader's inspections promote the policy implementation and adjustment.

\section{References}

Chen, X. M. (2000). Qualitative Research Methods and Social Science Research (p. 213). Beijing: Education Science Press.

Chen, Y. (1986). Chen's Anthology (p. 189). Beijing: People's Publishing House.

He, X. M. (2008). Government and Market: Roles of Local Government in Mutual Promotion-Basing on the Case Analysis of Zhejiang Phenomena. Zhejiang Social Sciences, No. 1.

Heilmann, S. (2008). Policy Experimentation in China's Economic Rise Studies in Comparative International Development (p. 43).

Li, J. C. (2014). Big Data and New Mind on Statistics. Statistical Research, No. 1, 12.

Lin, Y. F. (2014). The Relationship between Government and Market. Social Science in Chinese Universities, No. 6.

Mancur, O. (2005). Power and Prosperity (p. 3). Shanghai: Shanghai Century Publishing Group.

Roland, G. (2000). Transition and Economics: Politics, Markets and Firms. Cambridge, MA: MIT Press.

Xi, J. P. (2011). Interview Research Investigation. Party Building Research, No. 12.

Xi, J. P. (2013). Jinping Xi's Discussions about Chinese Dream of the Great Renewal of the Chinese Nation (p. 85). Beijing: Central Literature Publishing House.

Xi, J. P. (2016). Jinping Xi’s Discussions about Strict Party Discipline and Rules (p. 61). Beijing: Central Literature Publishing House.

Zhang, M. S. (2014). On the Two Main Aspects of the Relationship between Government 
and Market. Political Studies, No. 6.

Zhang, S. C. (2016). Regulating Central-Local Government Relations According to Law. Chinese Public Administration, No. 5.

Zhang, W. W. (2014). The Unique Advantages of China's Political System. Guangming Daily, 25.

Submit or recommend next manuscript to SCIRP and we will provide best service for you:

Accepting pre-submission inquiries through Email, Facebook, LinkedIn, Twitter, etc. A wide selection of journals (inclusive of 9 subjects, more than 200 journals)

Providing 24-hour high-quality service

User-friendly online submission system

Fair and swift peer-review system

Efficient typesetting and proofreading procedure

Display of the result of downloads and visits, as well as the number of cited articles Maximum dissemination of your research work

Submit your manuscript at: http://papersubmission.scirp.org/

Or contact ojps@scirp.org 